\title{
The Symbols of the Fire in Georgian Folklore in Comparison With Global Experience
}

\author{
Bela Mosia \\ Shota Meskhia State Teaching University of Zugdidi, Zugdidi, Georgia
}

\begin{abstract}
Fire is the world meaning symbol of wisdom, purification. Elements of place symbolism associated with fire are day time and specifically noon when the sun's light and heat is the greatest. The association with the sun makes fire an above space phenomena rather than a below or within space phenomena. The fireplaces have the same meaning for the houses like the sun for the earth. This paper is divided in several topics to show how the fire changes its meaning and how do peoples attitude to fire can be changed. Fire can represents in wedding ceremony, fire out of control makes chaos, destroying around everything from which arise the new life, and fire make the soul to be free from the sin. Fire, the eternal flame is the symbol of strong emotional feelings. The purpose of the paper is to give the interesting examples of fire symbols in Georgian folklore and make some similarities with world experiences. Georgian people as a part of ancient world make their own culture and in order to integrate Georgian materials in world cultural fund paper aims to make comparative work to achieve the main goal.
\end{abstract}

Keywords: fire, chaos, emotion, red

\section{Introduction}

This paper addresses one of the interesting symbols, symbol of the fire in Georgian folklore in comparison of world experience. The fire is known as a source of warm, purification, can emphasize strong feeling, and there are some very rare meanings of fire in Georgian reality people worship from the very ancient past. The research consist some parallels with world culture and world people attitude to the fire.

The nation of Georgia (Georgian) was first unified as a kingdom under the Bagrationi dynasty from the ninth to 10th century arising from a number of predecessor states of ancient Colchis and Iberia. The kingdom of Georgia flourished during the 10th-12th centuries and fell to the Mongols invasions of Georgia in 1243 and after a brief reunion under Giorge V of Georgia to the Timurid Empire. By 1490, Georgia was fragmented into a number of petty kingdoms and principalities, which throughout the early modern period struggled to maintain their autonomy against Safavid and Ottoman domination until Georgia was finally annexed by the Russian Empire in 1801. After a brief bid for independence with the Democratic Republic of Georgia of 1918-1921, Georgia was part of the Transcaucasian Socialist Federative Soviet Republic from 1922 to 1936, and then formed the Georgian Soviet Socialist Republic until the dissolution of the Soviet Union. The current Republic of Georgia has been independent since 1991.

The culture of Georgia has evolved over the country's long history, providing it with a unique national culture and a strong literary tradition based on a Georgian language and alphabet. This has provided the strong

Bela Mosia, professor, Humanitarian Faculty, Shota Meskhia State Teaching University of Zugdidi. 
sense of national identity that has helped to preserve Georgian distinctiveness despite repeated periods of foreign occupation.

The history of any countries is based on central historical sources like monuments of spiritual and material cultures, archeological evidences like monuments on the earth and under the earth, secular, and religious architectural monuments, ethnographic materials, written documents, and folklore, including linguistic materials, historical documents, epigraphic evidence, old inscriptions, coins called like numismatic evidence, works of literature, and foreign written documents. Georgia as a part of ancient cultural life is attractive for its unique traditions, national life, beliefs. Folklore and essential monuments of folklores like: Legends, ballades, myths, narrations, tales, songs, dances, charms, and omens etc. are the points of the author's interest as facts, sources of ancient culture. They are the evidence about world ancient culture as the other nations and cultures are.

\section{Ancient Fire Symbols}

As the main aspects of the author's scientific works are astral beings, on the author's work the author focus on the symbols of the fire in Georgian folklore and also on some traditions in Georgia connected with the fire as the fire is embodiment of the astral beings by meaning and form. How the fire makes the sense of heaven and how it can unify the world, earth, and heaven from down to up? We are all familiar with symbols because they pervade all our live. It is representation of ideas either in visual or audible form. The primitive culture, surrounded with harmful environment, surrounded with thunder, and frightened with everything and everyone, was looking for help in everything and everywhere. The main importance achievement of human was the fire, which helps him to avoid wild nature, wolves, and evil spirits. Ancient people were surprised with fire and were frightened with fire which was streaming from the land up to the sky and for this reason fire always was connected with supreme Gods and heaven. In primitive culture, people worship the fire as God and later fire was considered as an embodiment of Gods on the earth. Fire represents the sun and was considered as the symbol of the sun. In most ancient religions those two symbols, the sun and the fire, or mixed or fully equal to each other. The ancient religion of Iran Zoroastrianism is based on worship of fire, even the Mithra, developed independently from Zoroastrianism completely was based on the philosophy of fire. Well known ritual in Georgia, widely spread on Georgian territory is Chiakokona, sometimes considered as an fire worship from the Zoroastrianism, even contemporary life ritual of Chiakokona is celebrated in Georgia, it becomes like holiday and lost its ancient meaning but people still believe that jumping on the fire makes their life clean and this fire destroy the evil spirits under their legs. Georgian ritual chiakokona (jumping on the fire) has no connection with Zoroastrianism fire, it is the fire celebrity emphasize the sympathy to the fire, trying to make great bonfire, it is local, Georgian tradition from ancient past. According to the Buddha's tradition, one main symbol of Buddha is fire column and the fire light is the metaphor of wisdom. The place of fire in natural systems is represented by deserts and mountains. The deserts symbolize the quality dryness and heat associated with fire and the mountains symbolize the upward pyramid shape of fire. Similar to the element of fire which they represent, deserts have traditionally been associated with purification. Elements of place symbolism associated with fire are day time and specifically noon when the sun's light and heat is the greatest. The association with the sun makes fire an above space phenomena rather than a below or within space phenomena. A natural phenomenon which represents fire is lightning, and the phenomenon of fire out of control is symbolized by the forest fire. To say about fire: 
It is intimate and it is universal. It lives in our heart, it lives in the sky. It rises from the depths of the substance and offers itself with the warmth of love. Or it can go down into the substance and hide there, latent and pent-up, like hate and vengeance. (Bachelard, 1964, p. 44)

\section{Fire as the Symbol of the Sun}

The major symbolism of fire is related to the sun and the powers of transformation and purification. Its basic movement is upward rather than downward like water. Because fire warms and gives off light like the sun, it often represents the sun or sun God in mythology. In ancient Rome, the cult of the fire reincarnate into the fire on the fireplace. Vesta is the Roman goddess of fire and the hearth, whose circular temple in Rome was considered as central hearth of the city. Vesta represents the secret hearth or hearth of the home, the central fire which supplies heat and on which the food is cooked. In accordance of some Georgian traditions, the central fire in the fireplace was magical, and represent the sun and Georgian people worship it and believed if the fire blows down the misfortune will happen in family. Georgian curse: "be your fire blown down means desire to be destroyed the family. The fireplace was situated in middle of the house and was dividing the house in two parts: "The right part for men, left part for the women” (Chikovani, 1983, pp. 75-77). By Georgian beliefs the sun and the moon were introduces as female and male and the whole house was based on the life tree, which was the central part of the roof and under it was fireplace as the sun is the central creator under which he earth is living, giving to the earth the warms, light, and life, the fire in the middle of the house giving the house warms, light, and life. And the name of this life tree Georgian "Dedabodzi” means mother column. Beside the fireplace there was kept the snake, called as an angel of the house, keeping peace and happiness for the family. Snakes in the several shapes were represented several symbols and one and mostly important was the snake holding the tale in his mouth, like the ring as a symbol of the sun. The most important thing in Georgian tradition was that the snakes were kept in the milk to emphasize the sympathy to them. It is not accidental that snakes were kept in the milk. In sister language of Georgian Megruli, the sun and the milk has the same name, the word "Bjha = mze" for the milk and for the sun. In mythology, the sun and the milk were identified, one Georgian myth tells us why the sun and the milk have the same name:

One widow was milking the cow when the sun and the moon came and were glancing at her, she by anger throw the dung (muck) to them, the sun was able to purify in the milk but moon could not, so moon is hiding his face day time because of having dirty face. (Kiknadze, 1984, p. 119)

According to one Indian omen: "The sun has the great meaning for the agriculture, they were pouring the milk on the fire and they believe it helps to the sun to rise perfectly and it was the omen to worship the fire itself” (Nozadze, 1957, p. 15). Georgian phrase "you are not washed with the sun or milk” said for the true life and means you are not true, you are not right, purified or in the sun or in the milk as in Georgian the sun and the milk has the same name. Like the fire, the sun and the milk are purifying, too many examples of purifying in fire, with the same function the milk can clean the soul from the evil spirit. In Georgian myths, ladies like mermaids trying to fall in love with hunters, after they become beloved, men had problems with family, he could not serve the wife as husband, it was forbidden and he must follow the rules or mermaids will revenge, if anyone from the family, wife, mother or father follow him and during sexual intercourse with Mermaids, pour the milk on her hair, these ladies would have lost their magical power and becomes normal and usual. By this example even the hairs have magical function and as they are growing they were considered as they internally streaming to the sun. To sum up the magical meaning of the fireplace and the attributes around it they are the 
magical embodiment of the sun as in form also by meaning. The fireplace in the middle of the house was the holy place having sacral, sacred meaning. In the wedding tradition bride must walk around the fire three times to become the full member of the family. The Georgian name of the word wedding = kortsili, consists of two parts: kora and tsili and means the kora = house, family and tsili is part. "There is tradition within the Indian people to walk around holy fire and millstone stepping seven times with right leg on the stone” (Frazer, 1919, p. 293). Within the world people stones have been sacred to some spirit from ancient times. "Any man may find a stone for himself, the shape of which strike his fancy, or some other object, an octopus in his hole, a shark, an eel, which seems to him something unusual and therefore connected with a spirit” (Frazer, 1919, p. 63).

In Georgia some stones are having the hole in the middle considered as a holy stones, thunder stones and they are from the fire, the holes are from the heaven, thunder stones are kept at the gates of houses to keep the family from the evil spirits. "Some stones were sacred to various deities, whom the Greeks called Cronus, Zeus, the Sun, and so forth” (Frazer, 1919, p. 107).

\section{Fire as Symbol of Creation}

Fire is the active power takes part in the creation of the world. The existence of four basic physical elements—-fire, air, water, and earth—of which the entire world is composed. Making fires was the great epoch for mankind. The bringers of a fire are legendary heroes in many traditions. Prometheus of Greek mythology, one of the famous fire bringers, stole fire from the Gods and gave it humans. With this fire there were given to human various types of skills and knowledge. In Georgian mythology Amirani is the hero resembles classical Prometheus, like Prometheus he is punished and chained on Caucasus with his cursed dog Kursha and similar to the Prometheus an eagle, raven eat his liver but it heals every night. The child Amirani had marks of his semi-divines origins with symbols of the sun and the moon on his shoulder-blades and a golden tooth. Scholars agree that folk epic about Amirani must have been formed in the third millennium BC and alter went through numerous transformation, the most important of them being morphing pagan and Christian elements after the spread of Christianity. The myth could have been assimilated by the Greek colonists or travellers and embodied in the corpus of the famous Greek myth of Prometheus. In the Georgian literature and culture, Amirani is often used as a symbol of the Georgian nation, its ordeals and struggle for survival. Georgian Amirani stole the fired lady from heaven and let her living on the earth had been in love with her.

Fire is the symbol of chaos and war, There is an interesting relationship of fire with the symbolic place of Paradise. It shines in Paradise. It burns in hell. It is gentleness and torture. It is cookery and it is apocalypse, bringing nothing but ruin. Flames can bring punishment and suffering, as in the Christian image of hell as a place of fiery torment. Some myths of apocalypse predict that the world will end in fire-but it also may be a purifying, cleansing fire that will allow the birth of a fresh new world. In Indian mythology God of fire Agni represents three main aspects of fire: creator, defender, and destroyer. But fire can be the symbol of new life, as in the case of phoenix, the mythical bird that is periodically destroyed by flames to rise reborn from its own ashes. In many cultures people practise rituals related to the fire, these rituals are often based on myths and legends about fire or fire Gods. It is unbelievable that in this history of civilisation, the history of which was begun by making, taming the fire at the same time knows the very strict memories connected with the fire. Fire deities living under the earth request only people as a victim, only after immolation they will become kind and allow to the sun to be born in the morning again after sunset. The medieval inquisition was not only the war against magician but also it was somehow purification from unclean, all dirty. A little bit different attitude to 
the fire in antiquity. It was like mediator between exist and future life after death. It free the soul from the life, flesh, and body must be destroyed by the fire to make the soul free, this comes from the tradition of cremation. People keeping themselves from the fire away in some occasion, for example: "within the Indian tribes Pima, who will kill the apaches for next six days purifying in isolation, does not eat meat and salt, and does not look on fire” (Frazer, 1919, p. 63). Within Georgian people there are special illnesses, infectious diseases, called Batonebi $=$ Lords, people were keeping several taboos to avoid their bad effects, one of this never let to sick person look at fire or electricity.

\section{Fire as Symbol of Emotions}

Fire is also usually used for strong emotional feelings such as love, hate, desire, and determination, sometimes Love is spoken as an eternal flame. Fire and heat have been used to symbolize human emotions and particularly emotions associated with sexual power. In some tales it is linked with the idea of hearth, the center of the household. When the fire is eternal it can be enthusiasm, inspiration, but in the classical poem of Shota Rustaveli "The Noble in the Tiger's Skin" the fire is the conscience, internally killing the person, burning inside and makes spirit purified.

Fire is also related to the process of change. "Fire suggests the desire to change, to speed up the passage of time, to bring all life to its conclusion, to its hereafter” (Bachelard, 1964, p. 36). In this sense, all that changes slowly can be explained by life while all that changes quickly can be explained by fire. "Through fire everything changes” (Bachelard, 1964, p. 95). When we want everything changed we call on fire.

Fire has its color, colors of fires are the advancing colors of red and orange and the aspects of fire are flames and rays. Red color is considered as a color of the fire, flame, because flames and coals have a red coloration. From the red color of the fire comes the light, which is the symbol of spirituality. "This is massage we have heard from him and declare to you: God is light, in him there is no darkness at all” (John, 1:5-7). Light makes us to see things clearly so that we may be able to walk without falling, light gives us knowledge, and it is one of the means of perception. The sun, the fire, and the light were combined, united in New Testament when the Christ transfigured before his apostles: "There he was transfigured before them, His face shone like the sun, and his clothes became as white as the light” (New Testament, 2011, 17:2). The main color of the fire, red is the embodiment of light, light comes from fire is not visible, the no visible part of the fire become visible in red color, in flame, at the same time the red color of the sun was considered as an prediction of death, danger. Everything, happiness, danger, and death are the prediction from the heaven and also the life and safeness are the will of the heaven Gods.

\section{Conclusions}

To sum up the idea about fire symbols, according to Georgian tradition, fire makes the whole system of rituals and elements around it to unify the separate world and the fire with its universal nature makes the sense of perfection with all aspect of the life.

\section{References}

Bachelard, G. (1964). The psychoanalysis of fire. (A. C. M. Ross, Trans.). Boston: Beacon Press.

Bible. (n.d.). King James Version Bible (KJV). $\quad$ Retrieved from http://www.bibleing.com/versions/kjv.html?gclid=CO6aobHC5rwCFcIMcwodzy8AOg 
Chikovani, M. (1983). Hearth of mountain people's house, Achieve of the sector of Georgian-Caucasian cultural-historical relations. Tbilisi: Nakaduli.

Doane, T. W. (1882). Bible myths and their parallels in other religions being a comparison of the old and new testament myths and miracles with those of heathen nations of antiquity considering also their origin and meaning (4th ed.). (J. W. Bouton, Trans.). New York: The Truth Seeker Company 28 Lafayette Place.

Frazer, J. (1919). Folklore in Old Testament, studies in comparative religion. London: Macmillan and Co..

Inman, T. (1884). Ancient pagan and modern christian symbolism (4th ed.). New York: J. W. Bouton, Broadway.

Kiknadze, Z. (1984). King Pharnavaz’s dream. Journal Language and Literature, 1, 23-38.

New testament. (2011). Russian Bible Society. Tbilisi.

Nozadze, V. (1957). The sun lore in the “Knight in the Tiger's Skin”. San Tiago de Chile: Avtandil Merabishvili.

Tylor, E. B. (1871). (1989). Primitive culture: Researchers into the development of mythology, philosophy, religion, language, art and custom. New York: Henry Holt. 